\title{
Milksolids production from different combinations of perennial ryegrass and white clover cultivars: I Trial design and pasture performance
}

\author{
J.P.J. EERENS ${ }^{1}$, J.R. CRUSH ${ }^{1}$, S.L. WOODWARD ${ }^{2}$, K.A. MACDONALD ${ }^{2}$ and W.A. CARTER ${ }^{2}$ \\ ${ }^{1}$ AgResearch Ruakura, Private Bag 3123, Hamilton \\ ${ }^{2}$ Dexcel, Private Bag 3221, Hamilton \\ han.eerens@agresearch.co.nz
}

\begin{abstract}
A whole-farm systems comparison of combinations of perennial ryegrass and white clover cultivars rotationally grazed by dairy cows over two complete seasons evaluated improvements in perennial ryegrass and white clover cultivars resulting from plant breeding efforts. There were four treatments comprised of two ryegrass mixtures and two clover mixtures in a 2 × 2 factorial design, each replicated three times in a randomised block design giving 12, self-contained 4-ha farmlets each stocked at three multiparous Friesian cows/ ha. All pastures were sown in April 1998, using seed obtained through commercial sources, with a high endophyte ( $>70 \%$ endophyte infection) specification for the ryegrass cultivars. A grow out test, carried out after sowing, showed that two of the ryegrass cultivars used in the mix of older cultivars (80R) had less than $70 \%$ endophyte infection (Ellett 50\%, Nui 62\%, Yatsyn 94\%) resulting in an average endophyte infection of $69 \%$ for that mix. The mix of newer ryegrass (98R) cultivars had an average endophyte infection of 92\% (Aries HD 91\%, Bronsyn 98\%, Samson $87 \%$ ). While seedling densities (ryegrass and clover) were similar for all mixtures at the start, from late summer of the first year onward, tiller densities were around 30\% lower (due to predation of endophyte-free plants and tillers by the Argentine stem weevil) in the $80 \mathrm{R}$ treatment. The lower tiller density opened up the sward at an opportune time for clover expansion, which the newer clover cultivars (98C) Sustain and Challenge converted into a higher clover production than from the older clover cultivars (60C) Huia and Pitau. The 80R treatment had a greater spring surplus requiring more conservation than the 98R treatment, which had a more even growth distribution over the year. Differences in endophyte infection levels had a major impact on pasture composition, especially clover content; reducing the endophyte level of seed sown from $90 \%$ to $70 \%$ may create an opportunity to increase the clover content and quality of young pastures in the Waikato.
\end{abstract}

Keywords: cultivars, dairying, endophyte, perennial ryegrass, tiller density, white clover

\section{Introduction}

Research on perennial ryegrass and white clover pastures in New Zealand since the 1930s has not included evidence for increased milksolids production or dairy farm profitability from different cultivars. Results of dairy beef production trials in the Manawatu, which demonstrated higher animal production from pastures sown with new cultivars (Cosgrove \& Brougham 1988), were confounded because the old pasture controls were not ploughed and resown. McCallum \& Thomson (1994) compared performance of dairy cows grazing either Yatsyn 1, Embassy or Vedette ryegrass cultivar pastures during several shortterm trials. They concluded that ryegrass cultivar had little effect on milksolids production, although the trial design did not account for differences between cultivars in the amount of silage harvested. Some trials have demonstrated differences between clover cultivars in herbage production under dairy grazing (Moloney et al. 1988), but milksolids production was not measured. Small-plot trials under rotational dairy grazing in the Waikato region have shown only small differences in herbage production between ryegrass cultivars (Thom et al. 1998) and white clover cultivars (Woodward \& Caradus 2000). However, the ultimate test of cultivars should be their performance in realistic production systems where the effects of any differences in agronomic characteristics, and resultant animal production, can be monitored (Laidlaw \& Reed 1993). Laidlaw \& Reed (1993) point out, however, that a major difficulty of systems trials is that inadequate control and management can result in the interaction between management and herbage production either masking or enhancing any actual differences that may exist between cultivars.

This paper reports on the pasture aspects of a dairy farm systems experiment run for two complete seasons (1999/00 \& 2000/01), comparing pasture performance from farmlets based on combinations of perennial ryegrass and white clover cultivars. Animal aspects, milksolids production and farm profitability (Economic Farm Surplus; EFS) will be reported in the accompanying paper by Woodward et al. (2001). 


\section{Methods}

\section{Trial design}

The trial occupies 48 ha on the Dexcel's (previously Dairying Research Corporation) Scott Farm near Hamilton. One replicate of the trial is located on a Matangi silt loam soil and two replicates on Te Rapa silt loams and peaty silt loams (Stiles \& Singleton 1997). There are four pasture treatments consisting of mixtures representative of ryegrass cultivars available in the 1980s (80R), or late 1990s (98R), and the clovers of those available in the 1960s (60C), or late 1990s (98C) (Table 1). All ryegrass cultivars contained the highest endophyte level $(50 \%-98 \%)$ that are commercially available. Treatments paddocks were 1 ha in size, permanently split into two 0.5 -ha paddocks, using a randomised block design so that treatments were balanced across the range of soil types. Each treatment was replicated three times giving twelve, 4ha farmlets.

Table 1 Combinations, and the perennial ryegrass and white clover cultivars used in a farmlet study comparing different pasture mixtures in the Waikato over 2 years (1999-2001).

\begin{tabular}{|c|c|c|c|}
\hline Combination & $\begin{array}{l}\text { Ryegrass } \\
\text { cultivars }\end{array}$ & Endophyte & $\begin{array}{l}\text { Clover } \\
\text { cultivars }\end{array}$ \\
\hline 80R60C & Ellett, Nui, Yatsyn & $69 \%$ & Huia, Pitau \\
\hline 98R60C & $\begin{array}{l}\text { Aries HD, Bronsyn, } \\
\text { Samson }\end{array}$ & $92 \%$ & Huia, Pitau \\
\hline 80R98C & Ellett, Nui, Yatsyn & $69 \%$ & Challenge, Sustain \\
\hline 98R98C & $\begin{array}{l}\text { Aries HD, Bronsyn, } \\
\text { Samson }\end{array}$ & $92 \%$ & Challenge, Sustain \\
\hline
\end{tabular}

\section{Pasture establishment}

Existing pastures were sprayed with Roundup ${ }^{\mathrm{TM}}$, cultivated, and fallowed over summer, with chemical and mechanical weed control. The area was levelled and a power harrow was used to prepare the seedbed. Seed mixtures were sown during 10-13 April 1998 using a roller drill, harrows and a final rolling. Sowing rate (bare seed) was $18 \mathrm{~kg} / \mathrm{ha}$ total ryegrass and $3 \mathrm{~kg} /$ ha total white clover. Clover seed was Superstrike ${ }^{\mathrm{TM}}$ and Gaucho ${ }^{\mathrm{TM}}$ treated. Treatments were rotationally grazed by separate herds from mid-September 1998 to May 1999 to ensure that average total herbage dry matter (DM) was similar across all farmlets for the start of the 1999-2000 season.

\section{Cows}

All farmlets were stocked at three multiparous Friesian cows per hectare and were rotationally grazed. At the start of the 1999-2000 season, groups of cows allocated to farmlets were balanced for age, expected calving date, breeding worth, condition score, liveweight and where available, previous milksolids production.

\section{Management}

Fair comparison of treatments was supported by the use of written decision rules that were developed from previous farm systems trials at Dexcel (Macdonald \& Penno 1998). These rules determine management of length of grazing rotation, pasture silage conservation and feeding, target cow condition score and liveweight, drying-off of cows, and use of bought-in maize silage supplement and/or grazing-off. This meant that management decisions, which are typical of management on commercial, pasture-based dairy farms, could be made on an individual farmlet basis without compromising either the objectivity of the farmlets' management or expression of any treatment differences. Maintenance and nitrogen fertiliser application (maximum of $100 \mathrm{~kg} \mathrm{~N} / \mathrm{ha} / \mathrm{y}$ ), and the replacement heifer rate $(25 \%)$, were the same, however, across all farmlets.

\section{Measurements}

Pasture growth rate (kg DM/ha/day) and herbage accumulation ( $\mathrm{kg} \mathrm{DM} / \mathrm{ha}$ ) were derived from weekly visual assessment of herbage mass within every paddock on each farmlet. Visual assessment of herbage mass was calibrated each week against 10 herbage cuts $\left(0.33 \mathrm{~m}^{2}\right.$ frame) done on both pre-grazing and post-grazing pasture. Herbage was cut to ground level, washed (to remove soil contamination) and oven dried $\left(100^{\circ} \mathrm{C}\right.$ for 48 hours) to determine dry matter (DM). Pre-grazing botanical composition (herbage cut) was determined weekly on herbage cut along a transect by hand shears (leaving a stubble of approximately $3 \mathrm{~cm}$ ). Collected herbage was dissected into ryegrass (lamina and reproductive stem), other grasses, clover, weed and dead litter. Tiller plugs ( 30 cores, $50 \mathrm{~mm}$ diameter) were collected monthly from each farmlet and analysed for the number of ryegrass tillers and clover growing points. The endophyte infection level of ryegrass tillers was assessed on an annual basis on 100 tillers per treatment using immunoblot technology. Nitrogen fixation was measured in eight paddocks on a monthly basis using the ${ }^{15} \mathrm{~N}$ technique (Ledgard et al.1985). The nutritive quality of forage (separately for grass and clover) was determined twice in the first year using NIR technology. Data were analysed as a factorial randomised block using Genstat 5.

\section{Results and discussion}

\section{Endophyte infection and tiller dynamics}

Endophyte infection levels of the seed (grow out test), at sowing in autumn 1998, were $69 \%$ and $92 \%$ for the 
$80 \mathrm{R}$ and $98 \mathrm{R}$ treatments, respectively. These had increased to $93 \%$ and $98 \%$ in $1999,84 \%$ and $98 \%$ in 2000 and $88 \%$ and $96 \%$ in 2001 respectively. That the large initial difference in endophyte infection percentage was not maintained over time indicates that the endophyte-free plants/tillers were selectively removed by the Argentine stem weevil (Listronotus bonariensis) (ASW), which has been shown to prefer endophyte-free tillers to endophyte-infected tillers (Prestidge et al. 1992). The difference in preference for endophyte-free or infected tillers by ASW, tends to be greatest in summer/autumn when endophyte associated alkaloids are at their highest concentrations in the pseudostem of the ryegrass (Keogh \& Tapper 1993). As a result, the tiller density of the $80 \mathrm{R}$ treatments was significantly lower than that of the $98 \mathrm{R}$ treatment, a difference that was maintained up to the most recent measurements in April 2001 (Figure 1b). While the effect on ryegrass tiller dynamics was not unexpected once the difference in endophyte infection became known, there was an even greater impact on clover growing point dynamics (Figure 1a). Lower tiller numbers at the appropriate time gave white clover more open area to exploit, resulting in a higher clover content in the $80 \mathrm{R}$ treatments. This higher clover content was maintained up to the last tiller data recording presented here and was also reflected in a higher clover content of the pre-grazing standing herbage (Figure $2 \&$ Table 2).
Figure 1 Clover growing point $(A)$ and ryegrass tiller $(B)$ density at intervals over 2 years (1999-2001) for four combinations of perennial ryegrass and white clover cultivars (see Table 1), in a dairy farm systems trial in the Waikato. ${ }^{* * *},{ }^{* *},{ }^{*}$ and NS indicate $P<0.001, P<0.01, P<0.05$ and not significant respectively for the main factor printed at the end of the line.
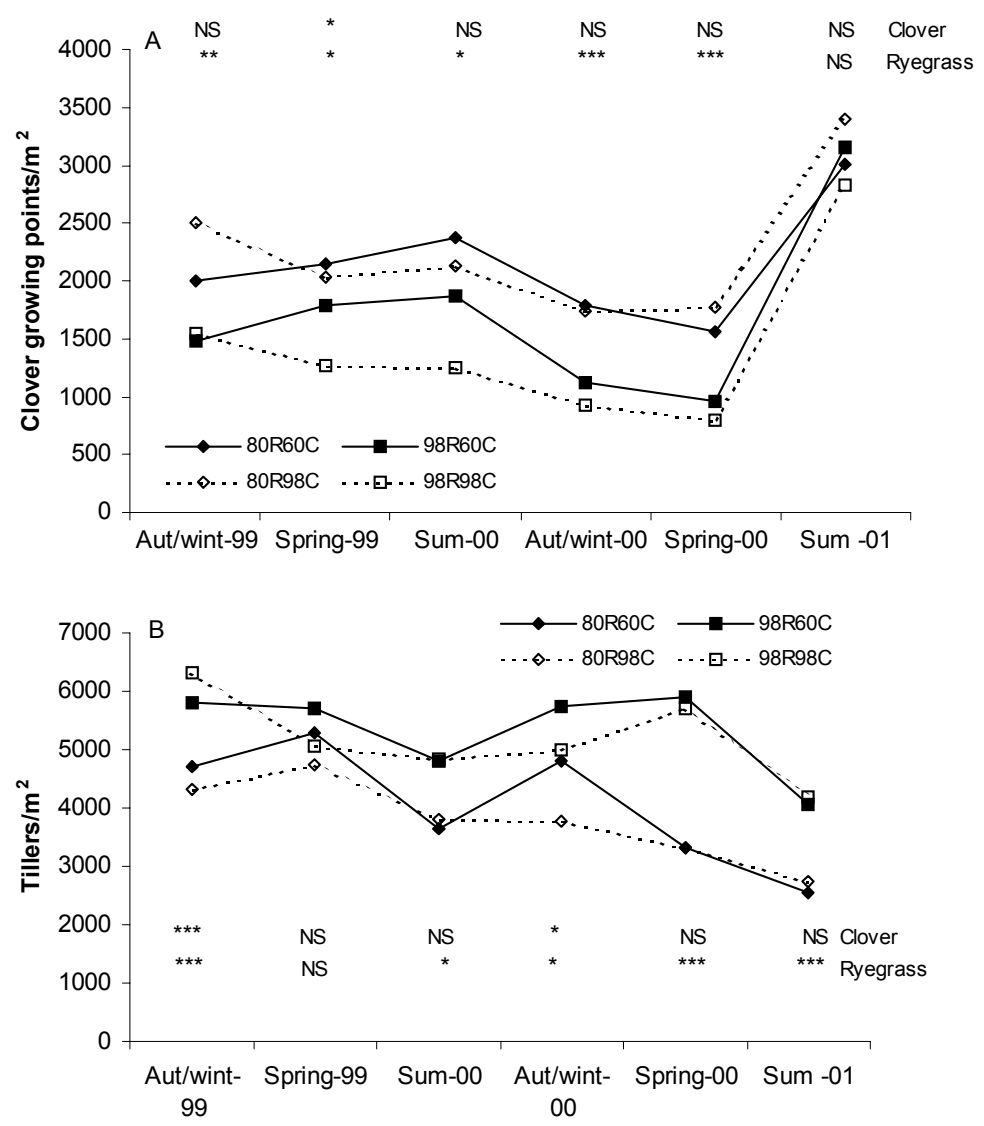

\section{Herbage composition, accumulation and pasture cover}

Total herbage accumulation was significantly $(\mathrm{P}<0.05)$ lower for the 80R60C treatment compared to the other three treatments (Table 2). This was largely due to lower total ryegrass production of the $80 \mathrm{R}$ compared to the $98 \mathrm{R}$ treatments, but in relation to the $80 \mathrm{R} 98 \mathrm{C}$

Table 2 Total herbage accumulation and seasonal botanical composition of four combinations of perennial ryegrass and white clover cultivars (see Table 1), in a dairy systems trial in the Waikato over 2 years (1999-2001) (kg DM/ha).

\begin{tabular}{lcccccrr}
\hline Combination & Ryegrass $^{*}$ & $\begin{array}{c}\text { Ryegrass } \\
\text { reproductive }\end{array}$ & $\begin{array}{c}\text { Other } \\
\text { Grass }\end{array}$ & Clover & Weed & Dead & Total \\
\hline 80R60C & $9,320 \mathrm{~b}$ & 640 & 330 & $2,510 \mathrm{ab}$ & 470 & 1,040 & $14,310 \mathrm{~b}$ \\
98R60C & $10,400 \mathrm{a}$ & 590 & 170 & $2,430 \mathrm{ab}$ & 540 & 1,060 & $15,190 \mathrm{a}$ \\
80R98C & $9,800 \mathrm{ab}$ & 500 & 290 & $3,160 \mathrm{a}$ & 600 & 980 & $15,330 \mathrm{a}$ \\
98R98C & $10,580 \mathrm{a}$ & 480 & 180 & $2,300 \mathrm{~b}$ & 670 & 1,110 & $15,320 \mathrm{a}$ \\
sed & 473 & 225 & 45 & 370 & 139 & 112 & 412 \\
\hline
\end{tabular}

*In columns, means without a letter in common differ significantly at $\mathrm{P}<0.05$ 
Figure 2 Contribution (\% of total DM) of white clover and perennial ryegrass to the average monthly dry matter pre-grazing herbage mass over 2 years (1999-2001) of four combinations of perennial ryegrass and white clover cultivars (see Table 1), in a dairy farm systems trial in the Waikato.

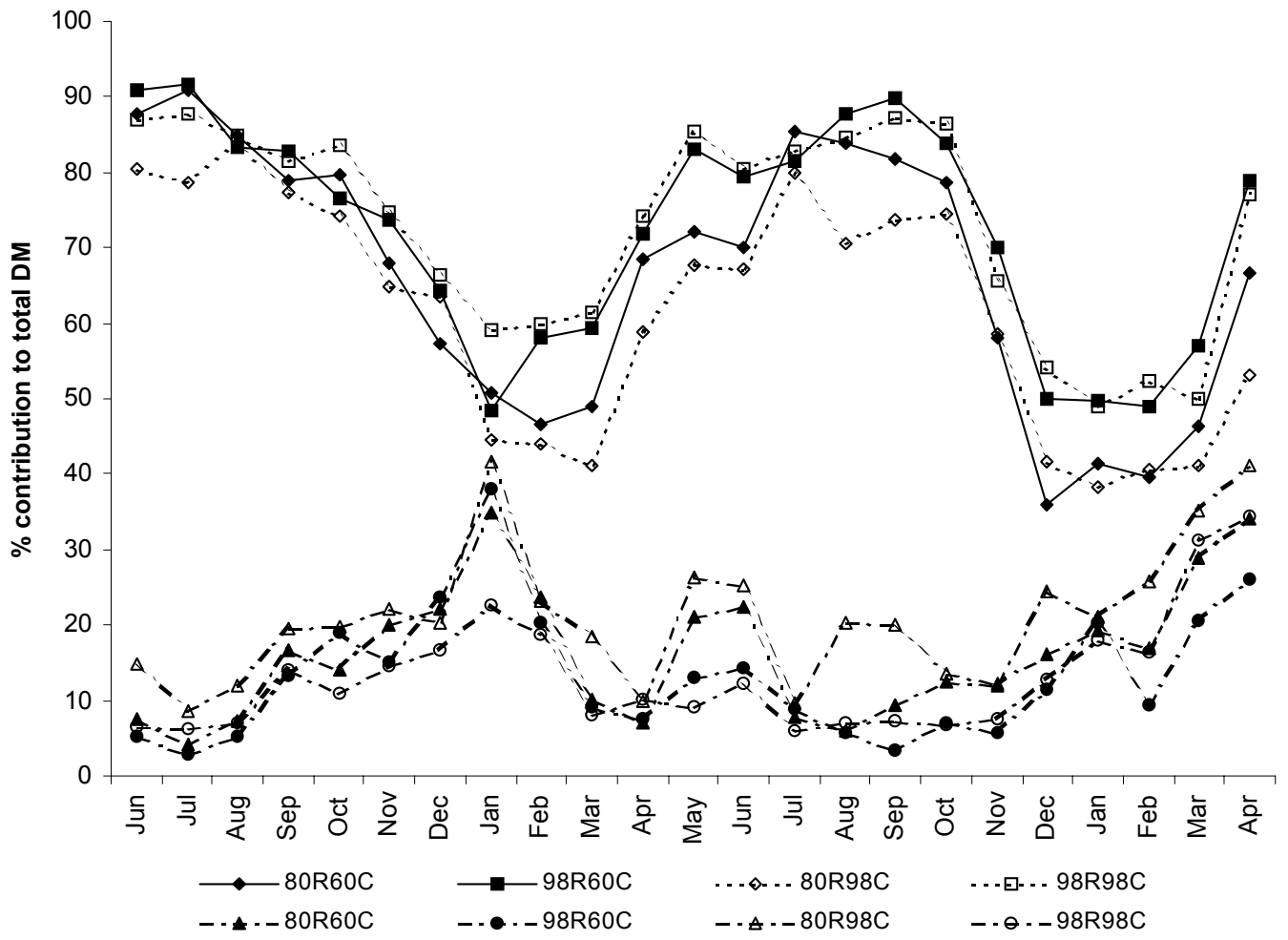

treatment it was due to a combination of lower clover and ryegrass production (Table 2 ). It appears from Figure 1a that both clover treatments exploited the extra space generated in the $80 \mathrm{R}$ treatments (as measured in the clover growing point density), but that only the Challenge and Sustain clovers converted this advantage into higher DM production (Table 2). Plant morphology may account for this observation, as the average leaf size and petiole length of Sustain and Challenge exceeds that of Huia and Pitau (Caradus et al. 1995). None of the other pasture components differed greatly between treatments.

Less pasture was conserved on the 98R treatments than on the $80 \mathrm{R}$ treatments in both years (Table 3 ). Plant breeders have targeted a more evenly distributed pasture growth curve to better match the nutritional requirements of stock and Figure 3 shows an advantage to the $98 \mathrm{R}$ ryegrasses in the late autumn/winter/early spring period, while the $80 \mathrm{R}$ ryegrasses exacerbated the feed surplus in spring. Whether the extra spring growth is an advantage depends on farmer preference. Aside from providing a source of supplementary feed for the farm system, closing a paddock for conservation
Table 3 Quantities of silage made (kg/cow) over 2 years (19992001) on four combinations of perennial ryegrass and white clover cultivars (see Table 1), in a farmlet study in the Waikato.

\begin{tabular}{lcc}
\hline Combination & 1999 & 2000 \\
\hline 80R60C & 200 & 160 \\
98R60C & 132 & 127 \\
80R98C & 195 & 301 \\
98R98C & 159 & 179 \\
sed & 40.3 & 44.0 \\
\hline
\end{tabular}

results in plants developing a deeper root system which, as happened in this trial, makes plants less susceptible to pasture pulling over summer especially at times when the black beetle (Heteronchys arator) reaches pest levels. Also, close cutting of the standing herbage will greatly reduce any aftermath heading.

\section{Nitrogen fixation and pasture chemical analysis}

Nitrogen fixation was highly correlated with the amount of clover produced, there were no differences between the treatments for nitrogen fixation per unit of clover DM produced. NIR analysis of ryegrass and clover 
Figure 3 Mean monthly herbage mass of the four combinations of perennial ryegrass and white clover cultivars (see Table 1 ) in a dairy farm systems trial in the Waikato, averaged over three replicates and 2 years (1999-2001). Error bars show the $\operatorname{LSD}(0.05)$.

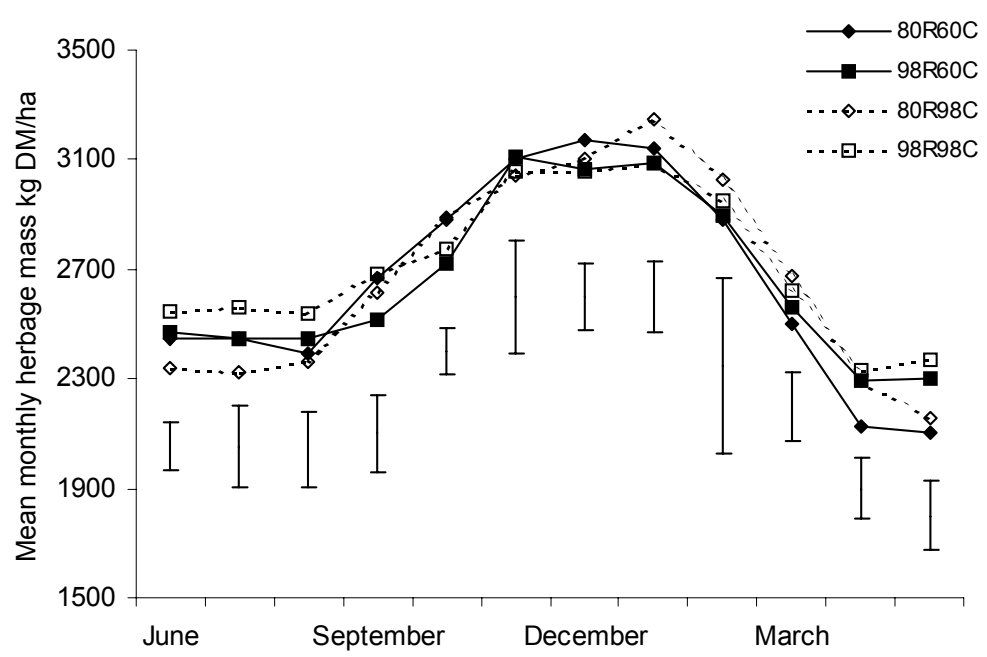

samples did not show any treatment differences in the concentration of the components measured (protein, lipid, ash, fibre (ADF \& NDF), soluble carbohydrates, digestibility or energy content).

\section{Summary}

The trial has shown over 2 years, a small benefit in terms of pasture composition to sowing newer white clover cultivars in combination with ryegrass cultivars moderately $(70 \%)$ infected with endophyte. This is assumed to have occurred because of greater tiller mortality rates in the low endophyte ryegrasses. The reduced tiller densities of these ryegrasses provided space that modern clover cultivars converted into extra production. These results point to a method for raising clover content of young pastures after a grass-to-grass renovation, something that will be further tested in a new experiment. The older ryegrasses produced a higher spring surplus than the newer ryegrasses, although on an annual basis the ryegrass component of the former produced less than that of the latter.

\section{ACKNOWLEDGEMENTS}

This research was fully funded by the New Zealand Dairy Board. John Caradus assisted with project management. Thank you to Shirley Nichols, Li Ouyang, Helen Simons, Liz Grayling and Elena Alley for the pasture measurements, and to the staff at the Dexcel Scott Farm for management of the trial.

\section{REFERENCES}

Caradus, J.R.; Hay, R.J.M.; Woodfield, D.R. 1995. The positioning of white clover cultivars in New Zealand. White Clover: New Zealand's Competitive Edge. Agronomy Society of New Zealand Special publication 11/ Grassland Research and Practice Series 6: 45-49.

Cosgrove, G.P.; Brougham, R.W. 1988. Pasture strategies for dairy beef production. Proceedings of the New Zealand Grassland Association 49: 57-62.

Keogh, R.G.; Tapper, B.A. 1993. Acremonium lolii, lolitrem $\mathrm{B}$, and peramine concentrations within vegetative tillers of perennial ryegrass. pp. 81-84. In: Hume, D.E.; Latch, G.C.M.; Easton, H.S. (Eds.) Proceedings of the Second International Symposium on Acremonium/ Grass Interactions.

Laidlaw, A.S.; Reed, K.F.M. 1993. Plant improvement: the evaluation and extension process. Proceedings of the XVII International Grassland Congress: $385-$ 392.

Ledgard, S.F.; Simpson, J.R.; Freney, J.R.; Bergersen, F.J. 1985. Field evaluation of ${ }^{15} \mathrm{~N}$ techniques for estimating nitrogen fixation in legume-grass associations. Australian Journal of Agricultural Research 36: 247-258.

Macdonald, K.A.; Penno, J.W. 1998. Management decision rules to optimise milksolids production on dairy farms. Proceedings of the New Zealand Society of Animal Production 58: 132-135.

McCallum, D.A.; Thomson, N.A. 1994. The effect of perennial ryegrass cultivars on dairy animal performance. Proceedings of the New Zealand Society of Animal Production 54: 87-90.

Moloney, S.C.; Hay, R.J.M.; Lancashire, J.A. 1988. The performance of Grasslands Kopu white clover on two dairy farms. Proceedings of the New Zealand Grassland Association 49: 97-100.

Prestidge, R.A.; Thom, E.R.; Marshall, S.L.; Taylor, M.J.; Willoughby, B.; Wildermoth, D.D. 1992. Influence of Acremonium lolii infection in perennial ryegrass on germination, emergence, survival, and 
growth of white clover. New Zealand Journal of Agricultural Research 35: 225-234.

Stiles, S.; Singleton, P. 1997. The distribution of soils on the AgResearch farm at Newstead. AgResearch internal report, $60 \mathrm{pp}$.

Thom, E.R.; Waugh, C.D.; McCabe, R.J. 1998. Growth and persistence of perennial and hybrid ryegrasses when grazed by dairy cows in the central Waikato region of New Zealand. New Zealand Journal of Agricultural Research 41: 477-486.
Woodward, S.L.; Caradus, J.R. 2000. Performance of white clover cultivars and breeding lines in rotationally grazed Waikato dairy pasture. New Zealand Journal of Agricultural Research 43: 323-333.

Woodward, S.L.; Macdonald, K.A.; Carter, W.A.; Eerens, J.P.J.; Crush, J.R. 2001. Milksolids production from different combinations of perennial ryegrass and white clover cultivars: II Milksolids production and conclusion. Proceedings of the New Zealand Grassland Association 63: 97-102. 